\title{
Fikcyjny Traktat Lizboński
}

$\mathrm{P}$ REZENTOWANY ARTYKUє ma na celu nakreślenie pewnych elementów sytuacji politycznej i prawnej, jakie wyłoniły się w związku z ratyfikacją i wejściem w życie Traktatu Lizbońskiego (TL), w płaszczyźnie najistotniejszych wyzwań stawianych przed reformą traktatową i przed samą Unią Europejską ${ }^{1}$. Nastąpi także generalna ocena zmian niesionych przez Traktat Lizboński dla funkcjonowania Unii Europejskiej. W niniejszym artykule staram się udowodnić tezę, iż z racji wyczerpania programu pogłębiania integracji europejskiej oraz w związku z okolicznościami niepowodzenia wejścia w życie Traktatu ustanawiającego Konstytucję dla Europy, głównym celem wprowadzania w życie TL, w szczególności po jego odrzuceniu w pierwszym referendum przez obywateli Irlandii, było potwierdzenie znaczenia i dynamizmu całego projektu jakim jest Unia Europejska.

Długo oczekiwany przez większość polityków, biurokratów, dziennikarzy TL wszedł w życie 1 grudnia 2009 r. Pytaniem, które pojawia się w tym kontekście, jest pytanie o sens forsowania tego aktu prawnego za wszelką cenę oraz realny wpływ jego postanowień na rozwój i przekształcenia Unii Europejskiej.

Jeśli spojrzeć na postanowienia TL można bardzo łatwo dojść do wniosku, co prawda przeciwnego niż powszechnie głoszonego przez większość polityków, iz jest to Traktat o charakterze porządkującym, przede wszystkim sankcjonujący zmiany, które w rzeczywistości w UE już funkcjonują, co dokładniej będzie przedmiotem analizy w dalszej części artykułu. Dlatego też jednocześnie należy odpowiedzieć na pytanie: dlaczego mimo to istniała tak ogromna presja na państwa członkowskie i obywateli Irlandii, aby TL został ratyfikowany?

${ }^{1}$ W tekście artykułu odwołując się do przepisów Traktatów, będę wykorzystywał Wersje skonsolidowane Traktatu o Unii Europejskiej i Traktatu o funkcjonowaniu Unii Europejskiej opublikowane w Dzienniku Urzędowym UE, Seria C 115, 09/05/2008 P. o001 - 0388; odwołując się do skrótów TUE (Traktat o Unii Europejskiej) oraz TFUE (Traktat o funkcjonowaniu Unii Europejskiej). 
Wyjaśnienie przyjęte w niniejszym artykule stwierdza, iż ogromny nacisk na forsowanie tego projektu związany był z koniecznością pokazania przez instytucje UE i polityków europejskich żywotności i witalności całego projektu, jakim jest Unia. Należy postawić pytanie, czy przyjęcie TL nie stało się celem samym w sobie, aby pokazać rozwój UE, a w praktyce jego postanowienia i ich wpływ na działanie UE miały charakter marginalny jako motywy działań większości państw członkowskich i instytucji UE w kontekście promocji powodzenia całego projektu.

Pytanie o sens realnych zmian prawa pierwotnego należy połączyć z pytaniem o możliwe do osiągnięcia cele samej Unii Europejskiej. W sytuacji, gdy nie mamy obecnie „wielkich projektów” jak w drugiej połowie lat 80-tych i w latach 90-tych dwudziestego wieku (projekt ukończenia budowy rynku wewnętrznego, Unia Gospodarcza i Walutowa), tym samym nie jest tak, iż zmiany w zakresie prawa pierwotnego mają umożliwić osiągnąc WE/UE jakiś głębszy poziom integracji europejskiej, jakkolwiek byśmy go nie rozumieli. Pojawia się pytanie o pewną granice rozwoju Unii Europejskiej w aspekcie pogłębiania współpracy pomiędzy państwami członkowskimi. Nie odnosząc się do pytania o ostateczny kształt tego, co jest dziś Unią Europejską, należy określić możliwe płaszczyzny pogłębiania integracji w przyszłości, czyli przestrzenie, które Unia mogłaby zagospodarować swoją aktywnością.

Najbardziej oczywistą jest kontynuowanie projektu unii politycznej, na którą składa się przede wszystkim współpraca w zakresie polityki zagranicznej oraz polityki bezpieczeństwa. Ewentualne postępy, jeśli w ogóle nastąpią, nie będą jednak zmianami o charakterze jakościowym, co najwyżej ilościowym. Jest to wynikiem ograniczeń strukturalnych Wspólnej Polityki Zagranicznej i Bezpieczeństwa (WPZiB) i Europejskiej Polityki Bezpieczeństwa i Obrony (EPBiO), a wynikających ze stosunku państw członkowskich do tych obszarów, które są praktycznie całkowicie domeną suwerennych praw członków UE. Patrząc na rozwój tego obszaru przez ostatnie kilkanaście lat, nie można oczekiwać w najbliższej przyszłości jakichkolwiek zasadniczych zmian w stanowiskach państw członkowskich do głębszej integracji w tym obszarze.

Drugim możliwym polem ekspansji działalności UE jest Obszar Bezpieczeństwa, Wolności i Sprawiedliwości (OBWiS). Szczególnie interesujące będzie włączanie dawnego trzeciego filaru w obszar prawny dawnego reżimu prawnego odnoszącego się do Wspólnoty Europej- 
skiej. Jednakże należy także pamiętać o pewnych specyficznych mechanizmach, które powodują, iż nadal w tym zakresie mamy pewne odmienności w procesie stanowienia prawa, które pozwalają zachować większą kontrolę państw członkowskich nad integracją w tym obszarze. Wydaję się, że OBWiS będzie jak w kilku ostatnich latach polem dynamicznej współpracy w ramach UE, jednakże i w tym kontekście pojawia się pytanie o „wielki projekt”, który mógłby być tu celem napędzającym rozwój całej UE, w przypadku WPZiB takim mitycznym celem jest wspólna polityka zagraniczna UE, która miałaby zastąpić politykę państw członkowskich czy równie nieokreślony projekt armii europejskiej. Natomiast w przypadku współpracy z zakresu wymiaru sprawiedliwości i spraw wewnętrznych nawet powołanie prokuratury europejskiej nie będzie czymś przełomowym, a tym bardziej na tyle istotnym, aby jednoczyć wokół tego celu państwa członkowskie i nadawać sens integracji europejskiej.

Przyjęty Traktat Lizboński potwierdza diagnozę, iż jedyne na co obecnie stać proces integracji europejskiej to usprawnianie procesu podejmowania decyzji oraz walka z „deficytem demokracji” (jeśli coś takiego $\mathrm{w}$ ogóle istnieje ${ }^{2}$ ), choć i tutaj niektóre przyjęte rozwiązania z tego punktu widzenia są mało znaczące, a inne kontrowersyjne. Postanowienia mało znaczące to te, które sankcjonują wcześniejsze praktyki dotyczące przebiegu procesu decyzyjnego. Należy tu wskazać zmiany w sposobie głosowania większością kwalifikowaną (o czym dokładniej poniżej), które wzmacniają pozycję najludniejszych państw członkowskich. Jednakże zgodnie z wcześniejszą praktyką, na co wskazały chociażby opisane w innym miejscu negocjacje dotyczące obsady nowych stanowisk unijnych, to RFN, Francja i Wielka Brytania podejmowały w swoim gronie decyzje najważniejsze, z drugiej strony, żaden projekt wysuwany czy to przez KE, czy państwo członkowskie, bez uprzednio uzyskanego poparcia ze strony przynajmniej dwóch z trzech wymienionych państw, nie miał szansy na przyjęcie go na forum Rady. Przykładem kontrowersyjnej zmiany jest obowiązek konsultacji aktów prawnych z parlamentami narodowymi państw człon-

${ }^{2}$ A. Moravcsik, jeden z główny badaczy UE kwestionuje stosowanie tego pojęcia do UE, gdyż stwierdza, iż należy odejść od idealistycznego pojmowania demokracji jako ustroju, a dokonać porównania funkcjonujących demokracji w Europie Zachodniej z systemem UE i na tej podstawie konkluduję, że w praktyce demokracja w Unii spełnia te same kryteria funkcjonowania jak demokracje państw zachodnioeuropejskich. A. Moravcsik, The Myth of Europe's “Democratic Deficit”, „Intereconomics: Journal of European Economic Policy" November - December 2008 s. 331 - 340. 
kowskich, jeśli spojrzeć na to z punktu widzenia szybkości procesu decyzyjnego, w szczególności (o czym niżej) gdy ich realna możliwość zablokowania niekorzystnego z ich punktu widzenia aktu prawnego jest niemożliwa, bez współpracy z Radą lub PE.

W związku z podjętą wcześniej próbą zastąpienia całego prawa pierwotnego przez Traktat ustanawiający Konstytucję dla Europy, jednym z głównych tematów dyskusji jakie pojawiły się w badaniach nad UE oraz jako temat powszechnie obecny w mediach była tzw. konstytucjonalizacja Unii Europejskiej ${ }^{3}$. Nie wdając się w rozważania co do precyzyjnego znaczenia samego pojęcia, należy tylko wskazać, iż nie można pojmować, jak wielu to czyniło, tego procesu poprzez pryzmat zmian o charakterze formalnym, czy de facto wprowadzania nazewnictwa, które miałoby świadczyć o nadaniu Unii Europejskiej konstytucji. Oczywiście pewne stanowiska teoretyczne, konkretnie związane $\mathrm{z}$ analizą dyskursu, czy niekiedy szerzej z konstruktywizmem, w tych faktach widziały zasadniczą zmianę jakościową. Natomiast autor niniejszego artykułu, stojąc na stanowisku racjonalistycznym, uważa, iż wprowadzanie zmian tylko o charakterze językowym, bez zmiany substancji danych elementów, nie ma realnego wpływu na kształtowanie rzeczywistości. Obecna struktura i sposób funkcjonowania UE powoduje, iż normy, które kształtują strukturę oraz reguły funkcjonowania, są de facto normami o charakterze konstytucyjnym. Jest to tzw. żywa konstytucja, która kształtuje się, szczególnie ostatnimi latami, przede wszystkim przez określoną praktykę oraz zmiany formalnoprawne, ale na poziomie podtraktatowym. Dlatego ważniejszym badawczo, ale i praktycznie, pytaniem jest problem kierunku i tempa tzw. pełzającego konstytucjonalizmu.

Analizując Traktat Lizboński, który jest elementem procesu kształtowania „żywej konstytucji”, trudno jednoznacznie zidentyfikować kierunek tego rozwoju. Jak wskazano powyżej główną osią zmian jest próba usprawniania funkcjonowania instytucji i poprzez to pośrednio całego systemu politycznego, a więc kierunek owego pełzającego konstytucjonalizmu można określić jako: konsolidacja i zwiększenie efektywności systemu instytucjonalnego oraz legitymizacji systemu politycznego.

${ }^{3}$ Zob. K. Bachmann, Konwent o przyszłości Europy. Demokracja deliberatywna jako metoda legitymizacji władzy $w$ wielopłaszczyznowym systemie politycznym, Wrocław 2004. 
Tym samym paradoksalnie porażka próby reformy konstytucyjnej, rozumianej z jednej strony jako upadek Traktatu Konstytucyjnego a z drugiej jako minimalistyczne podejście do reform wniesionych przez Traktat Lizboński, jest potwierdzeniem stabilności obecnie istniejącego europejskiego porządku konstytucyjnego ${ }^{4}$.

W kilku artykułach napisanych w związku z projektem i upadkiem Traktatu Konstytucyjnego oraz obecnie TL, Andrew Moravcsik, główny przedstawicieldominującego spojrzeniateoretycznegona UE, jakimjest liberalizm międzyrządowy, wskazuje na degresywny charakter zmian proponowanych przez te dwie propozycje zmiany prawa traktatowego, w stosunku do projektów jakim był Jednolity Akt Europejski (JAE) czy Traktat o Unii Europejskiej, powszechnie zwany Traktatem z Maastricht ${ }^{5}$. W artykułach tego autora można znaleźć zasadniczą krytykę obecnych zmian oraz stylu ich wprowadzania. W wielu argumentach przez niego prezentowanych należy przyznać mu rację. W szczególności A. Moravcsik obala argumenty osób, które widziały sens w forsowaniu tych projektów, szczególnie TK jako instrumentu mającego na celu zmniejszyć deficyt demokracja w UE oraz zwiększyć jej legitymizację. A. Moravcisk stwierdza, iż zwiększenie możliwości partycypacji obywateli nie prowadzi automatycznie do tego, iż ich udział w życiu politycznym UE się zwiększa, ponieważ jak wskazują przytaczane badania, sprawy, którymi zajmuje się Unia Europejska, dla obywateli mają trzeciorzędne znaczenie. Mają oni świadomość, że nadal głównym podmiotem wpływającym na ich codzienną egzystencję i możliwość realizowania podstawowych potrzeb jest państwo, tym samym brak jest motywacji do angażowania się w rozstrzyganie spraw na poziomie $\mathrm{UE}^{6}$.

Wysuwanie argumentu o potrzebie dokonywania zmian instytucjonalnych w związku z kolejnymi rozszerzeniami UE i stąd konieczność wprowadzania traktatów reformujących (TK i TL), także nie jest właściwym uzasadnieniem. Po pierwsze, wszelkie dostosowania instytucjonalne można wpisać w negocjowany traktat akcesyjny niezależnie od tego, czy miałby być one tylko ekstrapolacją istniejącego systemu, czy też jego zasadniczą reformą, gdyż należy pamiętać, iż takie zmiany traktatowe, podobnie jak normalne rewizje traktatów założy-

${ }^{4}$ A. Moravcsik, What Can We Learn from the Collapse of the European Constitutional Project? A Symposium, „Politische Vierteljahresschrift”, 47:2, s. 219.

${ }^{5}$ A. Moravcsik, The European Constitutional Settlement, „World Economy” Vol. 31 Issue 1, January 2008, s. $157-158$.

${ }^{6}$ A. Moravcsik, What Can...op. cit., s. $225-231$. 
cielskich muszą być ratyfikowanie przez parlamenty narodowe wszystkich państw członkowskich. Po drugie, w praktyce nastąpił pewien regres w stosunku do Traktatu Nicejskiego, jeśli chodzi o problematyczny, zbyt duży skład Komisji Europejskiej. Państwom członkowskim mogło wręcz zależeć na jak najszybszym ustanowieniu zmian, które znosiły system nicejski, wymuszający już od 2009 roku powołanie KE z mniej liczebnym składem komisarzy, niż jest państw członkowskich w UE. Natomiast w obecnym stanie prawnym (bardzo podobnie byłoby w przypadku wejścia w życie tzw. Traktatu Konstytucyjnego), reforma została odłożona przynajmniej do roku 2014, a istnieje możliwość, nawet po tej dacie, nie zmniejszania składu KE7.

Pomimo rozszerzenia wraz z każdą reformą traktatową zakresu spraw głosowanych większością kwalifikowaną (qualified majority voting - QMV) w Radzie, nadal ta instytucja w przypadkach, gdy prawo przewiduje głosowanie QMV, w ponad 90\% przypadków podejmuje decyzje na zasadzie konsensusu. W praktyce nawet system głosów ważonych, mający charakter degresywnie proporcjonalny czy preferujący państwa małe i średnie kosztem dużych, nie zapobiegł powstaniu rzeczywistości, w której to w praktyce i tak największe państwa członkowskie zawsze decydowały, w którym to kierunku powinien zmierzać proponowany kompromis. Przechodzenie od roku $2014^{8}$ na systemie QMV oparty na rzeczywistej liczbie ludności nie zmieni zbyt wiele, będzie tylko potwierdzeniem istniejącego obecnie stanu faktycznego. Dodatkowo należy zwrócić uwagę na mechanizmy zabezpieczające umieszczone w samym TL, które nakazują w przypadkach zebrania określonego procentu mniejszości blokującej (a nie samej mniejszości!) kontynuowanie negocjacji nad danym dossier. Obecnie, nawet w przypadku uzyskania przez prezydencję poparcia wymaganej QMV, poszukuje ona nadal poparcia dla danej propozycji we wszystkich państwach członkowskich, a fakt uzyskania QMV powoduje jedynie większą elastyczność ze strony państw członkowskich, które znajdują się w mniejszości, w zakresie forsowanych stanowisk, tak aby zbliżając się do osiągniętej już większości, mimo wszystko uzyskać pewne ustępstwa z jej strony, na rzecz przyjęcia danej decyzji poprzez konsensus. Dlatego też należy uznać, iż system QMV ma przede wszystkim charakter mobilizacyjny dla państw członkowskich w zakresie bardziej

${ }^{7}$ Art. 17 TUE oraz art. 4 Protokółu w sprawie rozszerzenia Unii Europejskiej, dołączonego do Traktatu ustanawiającego Wspólnotę Europejską w wersji nicejskiej.

${ }^{8}$ Art. 16 TUE. 
aktywnego i ugodowego osiągania porozumienia. Jak już zostało zaznaczone, oparcie QMV stricte na liczbie ludności będzie sankcjonować obecny stan, gdy to największe państwa członkowskie decydują i tak o kształcie podejmowanych decyzji. Czy poprzez zwiększenie zakresu spraw głosowanych większością kwalifikowaną w Radzie i zmianą samej formuły QMV doszło do wzmocnienia metody wspólnotowej czy międzyrządowej? Wydaje się jednak, iż fakt wzmocnienia dużych państw członkowskich, które przede wszystkim działają we własnym interesie, a interes samej Unii bardzo często schodzi na dalszy plan, a tym samym osłabienie państw mniejszych, powoduje, iż w tym zakresie należy jednak wskazywać na wzmocnienie metody międzyrządowej. Jak się wskazuje, to małe państwa członkowskie były od zawsze adwokatem wzmacniania pozycji ciał niezależnych od państw członkowskich.

Oceniając postanowienia o „zasadach demokratycznych”, należy stwierdzić na wstępie, iż Unia jako projekt polityczny (pewna idea zjednoczonej Europy z instytucjami wyposażonymi we władzę polityczną) był, jest i jeszcze długo zapewne zostanie projektem elit, eurokratów i kilku sektorowych grup interesu. Dla przeciętnego obywatela UE jest co najwyżej pewną płaszczyzną współpracy gospodarczej. Analizując sam TL, należy wskazać, iż po pierwsze, rola parlamentów narodowych ma zostać wzmocniona w procesie decyzyjnym, ale nadal będą to tylko pewne sygnały dotyczące ewentualnej niezgodności projektu aktu prawnego z zasadą pomocniczości, natomiast pozostanie brak realnej możliwości blokowania proponowanych rozwiązań. Wpisany wyraźnie obowiązek przekazywania propozycji przyjęcia aktów prawnych oraz innych dokumentów wydawanych przede wszystkim przez KE w praktyce występował już znaczenie wcześniej. Tak naprawdę problem realnego wpływu parlamentów narodowych na proces decyzyjny w UE rozwiązywany jest nie na linii instytucje UE - parlamenty narodowe, ale na linii parlamenty narodowe - rządy poszczególnych państw członkowskich, czyli na forum polityki wewnętrznej danego państwa członkowskiego.

Przepisy o demokracji przedstawicielskiej poprzez reprezentowanie obywateli przez posłów w PE oraz pośrednią kontrolę swoich przedstawicieli w Radzie Unii Europejskiej oraz w Radzie Europejskiej są tylko potwierdzeniem istniejącego stanu i nie przyznają obywatelom UE żadnych nowych uprawnień. Podobnie przepisy przede

\footnotetext{
${ }^{9}$ Art. $9-12$ TUE.
} 
wszystkim o charakterze deklaratoryjnym, dotyczące wsłuchiwania się UE w głosy obywateli, możliwość ich udziału w debacie publicznej czy wpływania poprzez różnego rodzaju organizacje społeczeństwa obywatelskiego na funkcjonowanie UE są tylko potwierdzeniem istniejącej praktyki, co do której nie należy przywiązywać w rzeczywistości większego znaczenia z racji ograniczonego sposobu ich wykorzystywania oraz mało efektywnego wpływu na rzeczywiście realizowane polityki UE.

Obywatelska inicjatywa legislacyjna, główny punkt projektu zwiększania wpływu obywateli na proces decyzyjny w UE, jest prawem, które w praktyce nie będzie miało większego znaczenia. Wymóg prawny zebrania co najmniej $1 \mathrm{mln}$ podpisów obywateli z obecnie nieokreślonej liczby państw członkowskich, brak wyraźnych regulacji co do charakteru obowiązku, jaki będzie ciążył na KE w momencie wpłynięcia takiego projektu, oraz przede wszystkim niskie zainteresowanie dużych grup obywateli sprawami rozpatrywanymi przez UE, powodują, iż już dziś można ocenić wprowadzenie tej instytucji jako elementu bardzo mało znaczącego dla praktyki politycznej UE. Podobnie politycy UE oraz państw członkowskich mają świadomość pewnej fasadowości tej instytucji, a więc znów należy zadać pytanie o sens tego typu działań. Czy możliwość złożenia takiej inicjatywy realnie wpłynie na stan demokracji w UE?

Jednocześnie pewnym paradoksem jest wprowadzanie TL tworzącego przynajmniej formalnie Unię bardziej demokratyczną, szczególnie z perspektywy obywateli, w taki niedemokratyczny sposób tj. poprzez forsowanie drugiego referendum w Irlandii w celu jego przegłosowania. Jeżeli w praktyce obywatele mają tylko jedną możliwą odpowiedzi w zakresie decydowania o przyszłości, rozwoju UE to powstaje pytanie jaki jest w ogóle sens pytania ich o zdanie. Jest to tylko niepotrzebna strata czasu, energii, środków finansowych oraz narażanie całego projektu na śmieszność. Błędem samym w sobie jest prosić obywateli o decydowanie o sprawach: po pierwsze które ich zasadniczo nie interesują; po drugie, o których nie mają wiedzy, gdyż przyjmowanie fikcji, iż jakakolwiek kampania przedreferendalna umożliwi zrozumienie sensu tych zmian jest po prostu nieporozumieniem. Demokracja powinna się opierać na ograniczonym, ale jednak w pewnym zakresie świadomym wyborze pomiędzy dostępnymi opcjami, natomiast jakiekolwiek referendum dotyczące zmiany traktatów założycielskim w żadnym wypadku nie spełnia tego kryterium. 
Czy wybór Przewodniczącego RE i Wysokiego Przedstawiciela był przykładem zasad demokratycznych, na których zgodnie ze zmienionym TUE ma opierać się „nowa” Unia? Osoba Przewodniczącego RE może spełniać określone ważne funkcje w zakresie jej działania, jednakże nie można się dziwić państwom członkowskim, szczególnie tym największym, iż nad jego zdolności przywódcze przedłożono jego zdolności mediacyjne. Czy przewodniczący forsowany zasadniczo przez Francję i RFN będzie miał silny mandat do wypełniania swojej roli w oczach pozostałych państw członkowskich? Czy jego pozycja i, co ważniejsze, rola nie będzie podobna do tej, jaką odegrał były prezydent Francji Valéry Giscard d'Estaing jako przewodniczący Konwentu w sprawie przyszłości Unii Europejskiej, czyli de facto reprezentanta interesów tych dwóch państw członkowskich. Można mieć nadzieję, iż jako obywatel Belgii będzie miał on bardziej na celu dobro całej Unii niż tandemu francusko-niemieckiego, jednakże ponieważ jest on wybierany na stosunkowo krótki czas i zapewne nadal chciałby pełnić tą funkcję, będzie miał tylko dwa i pół roku, aby wykazać swoją przydatność państwom, którym zawdzięcza swój wybór i ewentualną możliwość reelekcji. Dodatkowo fakt powiązania szefa państwa albo rządu państwa członkowskiego, które w danym momencie sprawuje przewodnictwo w Radzie, z przewodniczącymi poszczególnych formacji RUE (z wyłączeniem Rady ds. Zagranicznych) powoduje, iż każda propozycja forsowana przez Przewodniczącego RE musi mieć jego poparcie, tak aby możliwe było podjęcie decyzji prawotwórczej na poziomie RUE, dlatego wydaje się, iż to nadal szef państwa lub rządu sprawującego przewodnictwo w RUE będzie w znacznej mierze decydował o kierunku decyzji podejmowanych przez Radę Europejską.

Być może nie w pełni został dostrzeżony wpływ zasadniczej zmiany polityki zagranicznej i europejskiej RFN na funkcjonowanie i przyszłość całego projektu europejskiego. Odejście Niemiec od roli pierwszego sługi Europy pełnionej przez kilka dziesięcioleci i przejście na pozycje budowania swojej roli globalnej poprzez wykorzystanie zasobów udostępnianych przez jednoczącą się Europę, ukierunkowywanie ich na realizację celu, jakim jest ostateczne zrzucenie jarzma winowajców, państwa odpowiedzialnego za wywołanie drugiej wojny światowej po pięćdziesięciu latach integracji na kontynencie europejskim, powoduje, iż ten proces doczekał się zmiany jakościowej, mającej zasadniczy wpływ na jego przyszłość.

Niemcy jako państwo sprawujące prezydencję w pierwszej połowie 2007 były tym aktorem, który w praktyce zapewnił sukces kolejnej 
konferencji międzyrządowej (IGC). To ich przywódczyni Angela Merkel, była osobą w której pokładano nadzieję na rozwiązanie swego rodzaju kryzysu niemocy. Nie zwracano się o to do KE czy Parlamentu, ale właśnie do Niemiec. Poprzez bardzo restrykcyjne i stanowcze podejście RFN udało się bardzo dokładnie określić obszary spraw, które w ramach IGC będą podlegały negocjacjom, a także te, które zostaną pominięte i po prostu przeniesione z wcześniejszego projektu Traktatu. Niemcy w ten sposób właściwie wywiązały się z roli stawianej przed prezydencją, jednakże nadal pozostaje pytanie o kierunek obecnej polityki europejskiej RFN. Angela Merkel od czasów powołania Wspólnot jest kanclerzem traktującym integrację europejską najbardziej pragmatycznie spośród swoich wszystkich poprzedników. Brak jest obecnie w polityce niemieckiej jakichkolwiek rewolucyjnych koncepcji dotyczących UE, ta polityka jest nastawiona na trwanie UE jako podmiotu wspierającego realizację polityki wewnętrznej RFN. Podobnie postawa innych państw członkowskich naznaczona jest tym samym sposobem myślenia.

$\mathrm{Z}$ punktu widzenia następstwa prawnego, jakie nastąpiło pomiędzy WE a UE w płaszczyźnie prawnomiędzynarodowej ${ }^{10}$, nie należy w tym fakcie doszukiwać się istotnych konsekwencji prawnych. Koniecznością jest pamiętanie, iż przed wejściem w życie TL niektóry badacze przypisywali UE podmiotowość prawnomiędzynarodową z powodu możliwości zawierania umów międzyrządowych przez Radę w ramach II i III filaru. Jednocześnie nie ma wątpliwości, że te filary miały charakter międzyrządowy, a więc z faktu przekształcenia UE w organizację międzyrządową nie można wywodzić wniosku, iż wzmocni to charakter międzyrządowych tego podmiotu. Wręcz przeciwnie, należy zadać pytanie, jak długo będzie trwało rozciąganie przez ETS zasady pierwszeństwa i zasady bezpośredniej skuteczności norm obowiązujących do tej pory w ramach WE na dawny III filar. Tym samym dojdzie do powiększenie obszaru stosowania metody wspólnotowej.

Wyraźnie wskazanie kompetencji przyznanych UE (zasada przyznania $)^{11}$ jest istotnym krokiem w zakresie regulacji stosunków pomiędzy państwami członkowskimi a UE. Jednakże należy zwrócić uwagę, iż w praktyce nie nastąpiły tu istotne zmiany w stosunku do funkcjonującego wcześniej stanu prawnego, tzn. TL nie dokonuje przesunięć w zakresie kompetencji pomiędzy UE a państwami członkowski-

\footnotetext{
${ }^{10}$ Art. 1 TUE.

${ }^{11}$ Art. 4-5 TUE oraz art. $2-6$ TFUE.
} 
mi, które nie miałyby odzwierciedlenia w dotychczasowej praktyce. Warto także podkreślić, że w ostatnim okresie mieliśmy do czynienia raczej z oddawaniem przez WE pewnych spraw państwom członkowskim niż z kierunkiem odwrotnym, przede wszystkim w zakresie szeroko rozumianej polityki gospodarczej. Dawny art. 308 TWE (obecny 352 TFUE), obecnie w zmienionej wersji, niesie ze sobą dość ważne zmiany, mianowicie dochodzi rozszerzenie zakresu, w jakim UE może przyznawać sobie nowe uprawnienia konieczne do osiągnięcia celów zakładanych przez Traktat, uprawnień, których TFUE jej nie przyznał. O ile do 1 grudnia 2009 mogło to następować tylko w zakresie celów związanych z realizacją rynku wewnętrznego, o tyle obecnie dotyczy wszystkich polityk regulowanych w TFUE, a więc także tych wchodzących w skład OBWS.

Tym samym odrzucają uzasadnienie związane z realną koniecznością dokonywania zmian prawa pierwotnego czy z ich rewolucyjnym charakterem, co, jak zostało podniesione, wiąże się z usankcjonowaniem pewnej praktyki, a z drugiej strony z faktu, iż nawet dokonanie zmian w systemie głosowania nie spowoduje w praktyce odejścia od polityki konsensu rządzącej tym sposobem podejmowania decyzji, podobnie odrzucając argument dbałości o stan demokracji w UE, należy poszukiwać innego uzasadnienia dla podejmowanych reform. Tym uzasadnieniem jest obawa polityków państw członkowskich oraz przedstawicieli UE przed wejściem Unii w permanentny kryzys tożsamości. Ewentualne zablokowanie zmian po raz kolejny przez obywateli UE, a więc odmówienia legitymizacji temu projektowi byłoby zatrważające w sytuacji, gdy celem proponowanych zmian przynajmniej formalnie było zbliżenie UE do obywateli, demokratyzacji i legitymizacja tego systemu. Dlatego też niezależnie od realnego wpływu Traktatu Lizbońskiego na funkcjonowanie UE, jego wejście w życie było, z punktu widzenia rządów państw członkowskich i instytucji unijnych, najwyższą koniecznością. Czynnikiem, który może mieć ogromny wpływ na dalszy rozwój integracji europejskiej oraz UE, a który obecnie bardzo trudno określić, jest postawa orzecznicza Europejskiego Trybunału Sprawiedliwości. ETS już w przeszłości niejednokrotnie był propagatorem zmian o charakterze w praktyce rewolucyjnym dla funkcjonowania i przyszłości WE/UE, które to umożliwiły powstanie struktury o charakterze supranarodwym i quasifederalnym ${ }^{12}$.

${ }^{12}$ Pomimo użycia tych pojęć zdaję sobie sprawę z ogromnej ich niejasności i nieadekwatności, jednakże z racji dość ograniczonego aparatu pojęciowego dotyczącego okre- 
Obecnie politycy nie są zainteresowani dalszą integracją, gdyż w bezpośredni sposób oddziałuje to na ograniczenie ich władzy. Do tego brak jest czynnika, który w jakikolwiek sposób zachęcał ich do działań pogłębiających proces integracji. Ostatnim czynnikiem, nie mniej ważnym, jest brak zrozumienia i poparcia obywateli państw członkowskich dla jakichkolwiek kolejnych projektów związanych z rozwojem integracji europejskiej. Konsekwencją kolejnego zasadniczego kroku w ramach procesu pogłębiania integracji byłoby zniesienie państwa narodowego w Europie Zachodniej i Centralnej, co w obecnym systemie westfalskim nie jest możliwe.

\section{SUMMARY}

FROM THE POINT OF VIEW of many European politicians, the Treaty of Lisbon should enable great development in the functioning of European Union. However, having analyzed the amendments introduced by this Treaty, one has to admit that either most of the changes had already functioned in the EU political system before December 2009, as political practice, or the changes have no major impact on EU. Therefore, a question should be posed why Lisbon Treaty was such an important issue for politicians that they wanted to ratify it despite the 'no' voting in Ireland. The only reasonable cause that could lead politicians to such a move is the fact that integration is still a vital process for the existence of EU. Another failure of treaty amendments could be seen as the end of the European project.

\section{Nota O AUTORZE}

Adam Jaskulski [adam.jaskulski@amu.edu.pl] - magister w zakresie nauki o polityce, magister nauk prawnych. Obecnie doktorant w Pracowni Badań nad Integracją Europejską Wydziału Nauk Politycznych i Dziennikarstwa UAM w Poznaniu. Zainteresowania badawcze: prawo Unii Europejskiej, teorie i koncepcje integracji europejskiej, system instytucjonalny UE ze szczególnym uwzględniem problematyki prezydencji, polityka zagraniczna i bezpieczeństwa UE. Współredaktor książki: „Razem w sieci. Obywatele wobec zmian klimatycznych i przyszłości enegretycznej Unii Europejskiej”

Ślania UE w polskiej literaturze, te dwa pojęcia wydają się być najbardziej jednoznaczne oraz intersubiektywnie zrozumiałe. 